2009-11-01

\title{
Rendering Information Literacy Relevant: A Case-Based Pedagogy
}

Andy Spackman

andy_spackman@byu.edu

Leticia Camacho

leticia_camacho@byu.edu

Follow this and additional works at: https://scholarsarchive.byu.edu/facpub

Part of the Library and Information Science Commons

\section{Original Publication Citation}

Andy Spackman and Leticia Camacho, "Rendering Information Literacy Relevant: A Case-Based Pedagogy" The Journal of Academic Librarianship 35, no. 6 (29): 548-554.

\section{BYU ScholarsArchive Citation}

Spackman, Andy and Camacho, Leticia, "Rendering Information Literacy Relevant: A Case-Based Pedagogy" (2009). Faculty Publications. 118.

https://scholarsarchive.byu.edu/facpub/118

This Peer-Reviewed Article is brought to you for free and open access by BYU ScholarsArchive. It has been accepted for inclusion in Faculty Publications by an authorized administrator of BYU ScholarsArchive. For more information, please contact ellen_amatangelo@byu.edu. 


\title{
Rendering Information Literacy Relevant: A Case-Based Pedagogy
}

\section{This is a pre-print version of:}

Andy Spackman and Leticia Camacho, "Rendering Information Literacy Relevant: A CaseBased Pedagogy," The Journal of Academic Librarianship 35, no. 6 (2009): 548-554, doi:10.1016/j.acalib.2009.08.005

\section{Authors:}

Andy Spackman

Business and Economics Librarian

Brigham Young University

1212 Harold B. Lee Library

Provo, UT 84602

801-422-3924

andy_spackman@byu.edu
Leticia Camacho

Management and Accounting Librarian

Brigham Young University

1211 Harold B. Lee Library

Provo, UT 84602

801-422-1970

leticia_camacho@byu.edu

\begin{abstract}
:
The authors describe the use of case studies in a program of extracurricular library instruction and explain the benefits of case teaching in developing information literacy. The paper presents details of example cases and analyzes surveys to evaluate the impact of case teaching on student satisfaction.
\end{abstract}




\section{Introduction}

Brigham Young University, located in Provo, Utah, is home to the Marriott School of Management, which has an enrollment of 1,900 undergraduate and 1,100 graduate students. Business librarians conduct over 100 library instruction sessions for Marriott School students each year, the majority as part of a mandatory business communications course. During research consultations, students expressed a need for additional formal opportunities to learn what resources the library offers and how to use them. To meet this need and to offer more advanced instruction in specific subject areas, in September 2007 librarians added a program of extracurricular instruction in the form of open-door workshops inspired by the in-store clinics offered by The Home Depot. In an effort to bring the library to the students, the Business Research Clinics are conducted in business school computer labs rather than those in the central campus library. ${ }^{1}$

Librarians also adapted their style of teaching to the pedagogical model familiar to their students: the case method used in many business schools. This article will concentrate on the use of cases to teach business students information literacy skills. To assist in implementing a casebased pedagogy, the authors have established the Library Instruction Case Wiki (http://lib.byu.edu/casewiki), a repository for case studies, which is open to all librarians for both research and contribution.

\section{Literature Review}

The case method of instruction is a Socratic approach that took root at the Harvard Business School in the 1920s and has spread to business schools around the world. ${ }^{2}$ It consists of 
placing students in the context of real-life scenarios and, through discussion, encouraging them to see the full complexity of those situations and apply their own analysis in deriving a solution. As Barnes et al. explain, "The case method enables students to discover and develop their own unique framework for approaching, understanding, and dealing with business problems."3

Böcker demonstrated that case teaching increases student motivation and learning compared to lecture teaching. ${ }^{4}$ Robert Bruner, dean of the University of Virginia's Darden School of Business, calls the case method "learning that sticks."5

Librarians have published much literature discussing related instructional models: active learning, context-based, problem-based, and scenario-based. ${ }^{6}$ While these methods vary in their degree of complexity and the depth of student involvement, all attempt to make students active partners in the learning process, rather than teaching to the test or treating students as receptacles for traditional lecture-based instruction. Most authors agree that students learn and retain more when they are involved with the conditions of the problem, seek alternatives, and find their own solution. ${ }^{7}$ These interactive techniques promote "meaning-making, rather than fact-collecting.,"8 They allow students "the opportunity to apply library skills to the solution of meaningful problems, which makes the concept of information literacy immediate and relevant, rather than just another hoop to jump through in the process of earning a degree." 9

\section{Applying Case-Based Pedagogy to Library Instruction}

The purpose of case teaching as practiced in business schools is to immerse students in a complex situation in which they can apply the tools they have acquired. Unfortunately, typical business school case studies do not provide a good pattern for library instruction because they 
are self-contained (i.e., they include all pertinent information), and students are often prohibited from looking at outside information sources.

Case-based library instruction inverts this model. The case itself consists of a brief problem statement built around a narrative structure. This storytelling element captures student interest and accentuates the inductive and constructivist nature of learning through cases. The focus is on identifying what kinds of information would meet the needs of the case and exploring library and Internet resources to obtain such information. The objective is not to teach students how to conduct an analysis (that's their professors' job), but how to gather and assess the information they would need for an analysis.

Teaching with cases requires significant additional preparation on the part of the librarian. An effective instructor "must go beyond knowing the case well; the instructor should internalize the case to the extent of being prepared to conduct class without having to rely on notes." ${ }^{10}$ While the case itself may be simple, the librarian must create a scenario that students find compelling, that leads naturally to discussions about principles of information literacy, and that will highlight the resources the librarian wishes to introduce. To achieve this, the librarian needs to be familiar with the information needs students regularly encounter in their coursework and which they may anticipate in their future careers. Furthermore, because case studies allow students greater freedom in their problem solving, the flow of an instruction session may take unexpected turns, which requires librarians to spend much more time researching the scenario prior to an instruction session than the students will spend researching during the instruction session. 
Such intense preparation may increase the temptation to show students everything the library has to offer-what Paul Frantz describes as "a one-time, 50-minute dash through the library's 'greatest hits." ${ }^{11}$ As Kenney explains, this is exactly what the instructor must avoid:

Describing a laundry list of resources and services by lecturing and demonstrating is the antithesis of information literacy instruction that emphasizes user-centered, active learning and identified outcomes. The traditional role of demonstrator who provides lengthy explanations of how particular databases work and library services morphs into the role of a guide who helps focus students' problemsolving activities by shepherding them to the resources and asking pointed questions to keep them on task. ${ }^{12}$

The case teaching method allows principles of information literacy, as defined by the Association of College and Research Libraries' Information Literacy Competency Standards for Higher Education, to be introduced naturally. ${ }^{13}$ After explaining the premise of the case, librarians should lead a preliminary discussion in which students "[determine] the nature and extent of the information needed" (Standard One). Through a sequence of demonstrations and exercises, students gain experience "[accessing] needed information effectively and efficiently" (Standard Two). This interactive process provides opportunities for the librarian to help students "[evaluate] information and its sources critically" in the context of scenarios they might face in their future careers (Standard Three). The problem-based nature of case studies makes it possible for one-time library instruction sessions to achieve Standard Four: "The information literate student ... [uses] information effectively to accomplish a specific purpose," and this outcome can be demonstrated by requiring students to present their findings to their peers. Students often raise questions related to copyright, licensing restrictions, and access after graduation during the 
preliminary discussion or the wrap-up, allowing the librarian to address the ethical, legal, and socio-economic issues revolving around information use (Standard Five).

Three example cases for use in library instruction follow. In each students can work alone or in groups.

\section{Example Case 1: International Business}

\section{PREMISE}

This case is structured as a country screening and follows a logical progression, facilitating learning by evoking a narrative arc. Students' interest can be captured by placing the case in the context of current trends: "In 2007 the Nintendo Wii took the United States by storm, selling 6.3 million units at \$250 each, compared to 4.6 million units for Microsoft's Xbox 360 and 2.6 million for Sony's PlayStation 3. By November Nintendo's market capitalization was the second highest of any Japanese company, behind only Toyota. You've been hired to research markets outside Japan and the U.S. and tell Nintendo where to launch the Wii next."

\section{PRELIMINARY DISCUSSION}

A discussion of the kinds of information that will be useful for this scenario results in factors such as the demographics and prosperity of candidate nations' populations, the competitive environment, and the regulatory environment. This is followed by a discussion differentiating primary and secondary research and what kinds of information are available through the library. Qualitative discussions about free versus licensed resources are of particular interest to students who will soon be graduating but expect to experience similar information needs during their professional careers. 


\section{FIRST RESOURCE}

During the preliminary discussion students may have conjectured that a candidate nation should have a significant population of young people with adequate disposable income - the target demographic for game consoles. The librarian can now demonstrate a source for this kind of demographic and economic data, such as the World Bank's World Development Indicators database, or the freely available UNdata website (http://data.un.org/). The librarian then assigns students a specific objective, such as indentifying a handful of nations exhibiting the desired demographic and economic characteristics, and allows students several minutes to explore the resource with this purpose. One or two students can then describe their findings and reasoning to the rest of the class.

\section{SECOND RESOURCE}

In the preliminary discussion students may have suggested that knowing which competitors or suppliers operate in a nation would be useful, as would an awareness of local consumer behavior. However, not every information need can be addressed during a library instruction session nor can every resource be demonstrated, especially if students are to have hands-on experience with each resource. The librarian should demonstrate either a source for international company information, like Bureau van Dijk’s Mint Global database, or a source for international marketing information, like Euromonitor's Global Market Information Database. Attendees can then explore the resource on their own, seeking to narrow their handful of nations down to two or three nations, after which one or two volunteers present their findings. 


\section{THIRD RESOURCE}

Students may have discussed the importance of a business-friendly regulatory environment. The librarian can demonstrate free resources like the World Bank's Doing Business website (http://www.doingbusiness.org/) or the U.S. Commercial Service's Country Commercial Guides. Students should then use the resource to make a final selection, and one or two students can explain their decision.

\section{WRAP UP}

It is always beneficial to review the issues raised during the preliminary discussion, the principles of information literacy revealed through that discussion, and the ways that specific resources introduced during the discussion met the information needs voiced by students. The librarian should emphasize to students that there are probably additional information needs inherent in the case, and there are many other resources available. Distributing a handout that describes these additional resources helps the librarian remain focused on effectively introducing a limited set of resources. "Active learning hinges on the idea that less is more and that students are more likely to learn more if we provide less, but very focused and powerful, content."14

The librarian should remind students that the objective of the session was not to teach them how to conduct a country screening, but to demonstrate information-seeking strategies and resources that would be useful in conducting a country screening.

\section{Example Case 2: Entrepreneurial Marketing}

PREMISE 
Humor helps engage students in this case, in which the protagonist can be playfully caricatured as a comic book geek: "Large corporations and universities can afford premium sources of market research. But after graduation, if you go into business for yourself or work for a smaller company, what are your options? Herb Azaria wants to open a comic book store. He has some inventory in cardboard boxes in his garage, but he'll need to convince some investors or a bank to fund his dream. And he'll have to decide whether to open his store in Miami or to move back into his mother's basement in Boston and open his store there."

\section{PRELIMINARY DISCUSSION}

This case provides an opportunity to educate students about the cost of secondary market research. A Google search for market research on any given topic typically reveals a number of market research reports available for purchase at prices as high as several thousand dollars. However, there is a large amount of information freely available on the Internet through government agencies and other sources. Students can brainstorm the types of data that would help Herb write a convincing business plan and decide where to locate his store. The librarian can point out which of those data are available from free sources.

\section{FIRST RESOURCE}

Students will likely identify demographics as one factor in the decision about where Herb should locate his store. The librarian can demonstrate American Factfinder on the U.S. Census Bureau's website (http://factfinder.census.gov/) as a source for demographic data. Students may have identified young people as the target demographic, and they can now spend several minutes using American Factfinder to determine which city - Boston or Miami - has a higher population 
of young people and to identify possible reasons for this trend. The exercise may surprise some students: in $200637 \%$ of Boston's population was 15 to 34 years old, compared to $26 \%$ of Miami's, which is likely related to the fact that $13 \%$ of Boston's population are college or graduate students, compared to 5\% of Miami's population. Unexpected discoveries like this reward students' efforts and engage their interest.

\section{SECOND RESOURCE}

Knowing how much money people spend on comic books would help Herb build a business plan to impress potential investors or lenders. A good source for consumer spending data is the Bureau of Labor Statistics' Consumer Expenditure Survey (http://www.bls.gov/cex/). Unfortunately, the data are insufficiently granular to address a niche category like comic books. This provides an opportunity for the librarian to discuss strategies for coping with such obstacles when conducting research. Students can then spend time exploring the Consumer Expenditure Survey or the American Time Use Survey (http://www.bls.gov/tus/) for information that, while not specific to comic books, might nevertheless prove useful. One or two students can present what they find and explain its relevance.

\section{THIRD RESOURCE}

Time permitting, the librarian can introduce a new element to the case: "Herb also wonders whether creating a website for his store is worth the expense." Free sources of relevant information might include E-commerce statistics from the Census Bureau's E-Stats site (http://www.census.gov/eos/www/ebusiness614.htm) or data and reports from the Pew Internet and American Life Project (http://www.pewinternet.org/). After selecting and demonstrating a 
resource, students should be allowed time to explore it for relevant information, followed by one or two students presenting their opinions.

\section{WRAP UP}

While the challenges presented by this case cannot be resolved in an hour-long session, it is important to remember that the purpose of using case studies in library instruction is not to discover a correct answer for the case but to discover principles of information literacy and learn research strategies. A review of the resources covered and the types of information they offer provides an opportunity to underscore these learning outcomes.

\section{Example Case 3: Building a Company List PREMISE}

This case takes a more focused look at a single type of information resource: "Your team is performing a competitive analysis for a freight trucking company headquartered in El Paso, Texas. Your current task is to create a list of local competitors and lists of top competitors across the United States and Mexico.”

\section{PRELIMINARY DISCUSSION}

The limitations of Internet searches and online yellow pages can be demonstrated as part of a discussion about what kinds of information should be included in such a company list. Beyond company name and address, students will likely mention revenue, assets, number of employees, market capitalization, major shareholders, and so on. They may also mention industry-specific data, like operating territory and fleet size, which would provide an opportunity 
to discuss the limitations of general sources of company information and the potential for more industry-specific sources of information.

\section{RESOURCES}

There are a number of databases with company information that can be used to create lists of companies that meet given search parameters. Examples include Hoover's, Reference USA, LexisNexis, and Bureau van Dijk's Mint Global database. The purpose of this case is to introduce students to two or three of these and allow them to compare and contrast the different tools.

\section{EXERCISES}

In this case the first task may be to identify an appropriate industry code to use in searching the databases. The U.S. Census Bureau's North American Industry Classification System (NAICS) website is useful for this (http://www.census.gov/eos/www/naics/). Industry classification systems will be new to many students, and this is an opportunity to introduce concepts related to the organization of information.

Brief demonstrations of the company databases can be followed by exercises in which students discover how many freight trucking companies each database lists for the El Paso region, the United States, and Mexico. The variance in the number each database reports leads to a discussion about how each database gathers data and the possible inclusion of branch locations, subsidiaries, and companies for whom freight trucking is only a secondary line of business. The variance can also lead to a discussion of the extent of each database's coverage of local, national, and international companies. 
Students should compare entries for a specific company across each database, allowing for discussion of further differences in how each gathers and reports data. Entries for different types of companies should also be compared in order to trigger a discussion of the three factors that govern how much information is available on a company and how reliable it is: whether it is a public or private company, how large it is, and how transparent the financial systems are in the company's home nation.

Finally, the librarian can demonstrate additional screening criteria and features for company comparisons, analysis, and exporting, printing, or saving company lists.

\section{WRAP UP}

The tight focus of this case allows for a deeper exploration of a specific kind of database, but it will likely leave students wondering where to turn for other kinds of related information. After reviewing the session's learning outcomes, the librarian can briefly outline the kinds of resources that might supply such related information. This overview can be accomplished more thoroughly through handouts.

\section{Does a Case-Based Pedagogy Improve Student Satisfaction?}

Librarians at Brigham Young University find sessions structured around case studies to be personally rewarding and feel more confident our efforts in such sessions are successful. Students attending Business Research Clinics have been surveyed to discover whether they share these positive perceptions.

\section{Methodology}


Paper surveys are distributed to attendees at the beginning of clinics. Attendees are invited to complete the survey and return it at the end. Over the course of three semesters, librarians conducted 36 clinics on 17 topics, with a total attendance of approximately 520 (in an open-door clinic, attendees are free to come and go, making it difficult to count attendance precisely). Attendees returned 288 completed surveys, representing approximately $55 \%$ of attendees. Of the 288 completed surveys, 121 surveys, or $42 \%$, were from clinics structured around case studies.

In addition to evaluating student satisfaction, the survey instrument informs promotional efforts by documenting whether students are learning about clinics through posters, fliers, professor recommendations, and so on. Surveys also provide information regarding attendees' areas of study and invite them to suggest future clinic topics and add their e-mail address to the mailing list.

\section{Results}

The first three questions on the survey ask respondents to rate their overall experience of the clinic, the content of the clinic, and the instructors on a one-to-seven Likert scale. A modest difference is observed between mean attendee satisfaction for clinics conducted in a traditional mode versus those organized as case studies. As shown in Table 1, clinics structured around cases are rated 3.5\% higher for overall experience, $4.8 \%$ higher for content, and $2.8 \%$ higher for instructors.

An independent samples t-test reveals p-values of 0.144 for overall experience, 0.033 for content, and 0.160 for instructors, meaning that only in the case of content can it be said with 
greater than $95 \%$ confidence that the difference observed between mean ratings of case-based and traditional clinics is not a result of random variation.

In addition to structuring some clinics around case studies, a smaller number of clinics included competitions with prizes for participants. The first attendees to correctly use the demonstrated resource to obtain appropriate information receive prizes, including candy, books, and humorous items. Of the 288 completed surveys, 43 surveys, or 15\%, resulted from clinics organized in this manner. Contrasting this approach with case-based pedagogy reveals a much less significant difference in student satisfaction. As shown in Table 2, sessions in which prizes were awarded rated $1.1 \%$ lower than those without prizes for overall experience, $0.5 \%$ higher for content, and $1.2 \%$ higher for instructors. Interestingly, clinics with case studies rated $2.9 \%$ higher than clinics with prizes for overall experience and $2.3 \%$ higher for content, while only rating $0.6 \%$ higher for instructors.

\section{Analysis}

Because satisfaction with content is most positively related to case-based pedagogy and involving prizes in a clinic appears to improve instructor ratings more than content or overall experience, one might conclude that case studies more effectively communicate a clinic's content, while awarding prizes endears the librarian to the student. However, t-tests resulting in p-values of 0.754 for overall experience, 0.877 for content, and 0.666 for instructors suggest that the observed differences in mean ratings for clinics with prizes are most likely the result of random variation, whereas the increase in mean satisfaction for content is correlated to casebased pedagogy with $95 \%$ certainty. 
It must be said that even though the use of case studies positively correlates to higher ratings of satisfaction with clinic content, the mean increase of $4.8 \%$, or about three-tenths of a point on the Likert scale, may have little practical significance. It remains for the librarian to determine whether this difference merits the additional preparation case-based pedagogy requires. Anecdotal evidence may carry weight in this decision. Comments on surveys resulting from case-based clinics have been universally positive, both from students-“"The role-play scenario was helpful!" — and from professors_-"I like that you're doing this and have heard good things from students attending when you do a case study." This suggests that the relationship between case studies and student satisfaction is not only correlative but causal, at least for those individuals making such comments.

\section{Opportunities for Further Research}

Anecdotal evidence and the marginally significant difference observed in student satisfaction indicate that further research is warranted. The methodology described in this study is fraught with uncontrolled elements. Survey respondents not only self-select in completing the survey, but in attending the clinic in the first place. Variations in clinic topics, students' majors, and the instruction styles of different librarians may also distort the survey results.

Even the kind of promotional effort that brings students to a clinic might affect their satisfaction. For example, average satisfaction ratings are higher for those who became aware of the clinic because of posters than for those whose professors recommended clinics (see Table 3). It may be that those who attend because of a professor's recommendation are more difficult to satisfy because they feel compelled to attend or are coming with exaggerated expectations, whereas those who became aware of clinics through posters come with more open minds or, 
having self-selected, are more committed to benefiting from their attendance. However, t-tests reveal that these differences are too inconsistent across survey respondents to be considered statistically significant.

Future studies should seek to establish student satisfaction in a more controlled environment and to determine causality. They should also look beyond satisfaction and measure the impact on learning outcomes caused by the use of case studies: Do cases result in improved learning and retention? Do they result in improved performance on class assignments? Do they increase information literacy?

\section{Conclusion}

Case teaching, core to so many business schools, is an effective pedagogical approach that can be adapted to a library instruction context. Though it requires additional preparation, it allows librarians to introduce principles of information literacy in the natural course of an active learning process.

Student surveys reveal slightly higher mean satisfaction ratings for clinics organized as case studies, though only in ratings of satisfaction with clinic content can improved ratings be correlated to case studies with $95 \%$ confidence. This increased satisfaction is supported by anecdotal evidence.

Further research is needed to corroborate these marginally significant findings and to determine whether case teaching affects learning outcomes. It may be that case teaching is more effective only in certain situations or for certain subject areas.

The example cases in this article are included in the Library Instruction Case Wiki, along with additional cases (http://lib.byu.edu/casewiki). We invite others, especially those with 
different subject backgrounds, to develop their own cases and post them on this wiki for all librarians to share. 
Spackman and Camacho, p. 19 of 22

\section{Notes and References}

1. For further discussion of the origin and implementation of the Business Research Clinics, see Andy Spackman and Leticia Camacho, "Integrated, Embedded, and Case-Based: Selling Library Instruction to the Business School," in Librarian as Architect: Planning, Building and Renewing: Thirty-Sixth National LOEX Library Instruction Conference Proceedings, edited by Brad Sietz, Susann deVries, Sarah Fabian, Suzanne Gray, \& Robert Stevens (forthcoming from Ypsilanti, MI: LOEX Press, 2009).

2. David A. Garvin, "Making the Case: Professional Education for the World of Practice," Harvard Magazine 107 (September-October 2003): 56-65.

3. Louis B. Barnes, C. Roland Christensen, and Abby J. Hansen, Teaching and the Case Method, 3rd ed. (Boston: Harvard Business School Press, 1994), p. 42.

4. Franz Böcker, "Is Case Teaching More Effective than Lecture Teaching in Business Administration? An Exploratory Analysis,” Interfaces 17, no. 5 (1987): 64-71.

5. Robert Bruner, “Why Do We Discuss Cases?” Dean's Blog, Robert Bruner, Dean Darden School of Business. (January 1, 2008) Available: http://www.darden.virginia.edu/html/deansblog.aspx?id=12694 (December 5, 2008).

6. For examples, see Barbara Ferrer Kenney, "Revitalizing the One-Shot Instruction Session Using Problem-Based Learning," Reference \& User Services Quarterly 47, no. 4 (2008): 386-391; Edward A. Henninger and Janet McNeil Hurlbert, "Critical Thinking and Information Across the Undergraduate Business Curriculum," Journal of Business \& Finance Librarianship 2, no. 1 (1996): 29-40; Alexius Smith Macklin, “Integrating Information Literacy Using Problem-Based Learning," Reference Services Review 29, no. 4 (2001): 306-313; Roldan Malu and Yuhen Diana Wu, "Building Context-based Library 
Instruction," Journal of Education for Business 79, no. 3 (2004): 323-327; and the series of four articles in Portal: Libraries and the Academy about problem-based library instruction at Penn State, beginning with Larry Spence, “The Usual Doesn’t Work: Why We Need Problem-Based Learning," Portal: Libraries and the Academy 4, no. 4 (2004): 485-493.

7. Patricia R. Krajewski and Vivienne B. Piroli, "Something Old, Something New, Something Borrowed, Something Blue: Active Learning in the Classroom," Journal of Library Administration 36, no. 1/2 (2002): 177-194.

8. Paul Frantz, “A Scenario-Based Approach to Credit Course Instruction,” Reference Services Review 30, no. 1 (2002): 38.

9. Linda Carder, Patricia Willingham, and David Bibb, "Case-Based, Problem-Based Learning: Information Literacy for the Real World." Research Strategies 18, no. 3 (2001): 189.

10. Ram Charan, "Classroom Techniques in Teaching by the Case Method," Academy of Management Review 1, no. 3 (1976): 117.

11. Frantz, “A Scenario-Based Approach,” p. 37.

12. Kenney, "Revitalizing," pp. 387-388.

13. Association of College and Research Libraries, Information Literacy Competency Standards for Higher Education (Chicago: Association of College and Research Libraries, 2000).

14. Annie Downey, Lilly Ramin, and Gayla Byerly, "Simple Ways to Add Active Learning to Your Library Instruction,” Texas Library Journal 84, no. 2 (2008): 52. 


\section{Appendix: The Business Research Clinics Survey Instrument}

\section{BUSTINGSS RBSBARCH CHINIC}

Participant Survey

Securities Analysis - October $24^{\text {th }}, 2007$

Thonk you for ottending todoy's Business Research olinic. Pleose help us improve the clinics by completing this suney and retuming it to the librorions.

1. Please rate your overall experience. (circle a number, $1=$ Poor, $7=$ Excellent)

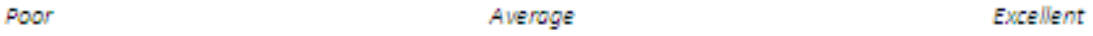

2. Please rate the content of the clinic.

3

45

Please rate the instructors.

$\begin{array}{llllllll}1 & 2 & 3 & 4 & 5 & 6 & 7\end{array}$

4. Will you attend future clinics? __es _ No _ _ Depends on Topic

5. Would you recommend the clinics to others? _Yes _ No

6. How did you learn about this clinic?

_ Posters

_Professors

_Fliers

- Other students

I'm on the email list

7. Check all that describe your program/department:

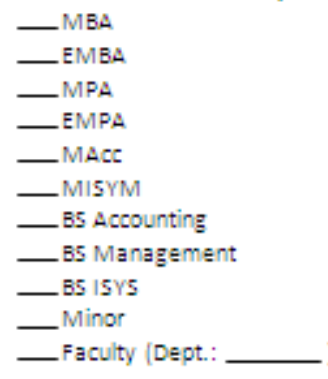

Track (if apolicable):

Entrepreneurship

- Finance

L Marketing

$\mathrm{OB} / \mathrm{HR}$

PhD Track

Product Development

Supply Chain Management

Strategy

Tax

8. What topics or research problems would you like to see covered in future clinics?

9. Would you like to receive emails announcing future clinics?

_ Yes _ No _ _ already do Email address:

10. Please write any other comments or suggestions on the back. 
TABLE 1. Attendee satisfaction ratings for clinics with case studies versus those without.

\begin{tabular}{|cccc|}
\hline & $\begin{array}{c}\text { (1) Please rate } \\
\text { your overall } \\
\text { experience. }\end{array}$ & $\begin{array}{c}\text { (2) Please rate the } \\
\text { content of the } \\
\text { clinic. }\end{array}$ & $\begin{array}{c}\text { (3) Please rate } \\
\text { the instructors. }\end{array}$ \\
\hline $\begin{array}{c}\text { Average ratings for sessions } \\
\text { without case studies }(N=167)\end{array}$ & 5.50 & 5.65 & 5.92 \\
\hline $\begin{array}{c}\text { Average ratings for sessions } \\
\text { with case studies }(N=121)\end{array}$ & 5.69 & 5.93 & 6.08 \\
\hline $\begin{array}{c}\% \text { Increase of sessions with } \\
\text { case studies over those without }\end{array}$ & $3.5 \%$ & $4.8 \%$ & $2.8 \%$ \\
\hline
\end{tabular}

TABLE 2. Attendee satisfaction ratings for clinics with prizes versus those without.

\begin{tabular}{|cccc|}
\hline & $\begin{array}{c}\text { (1) Please rate your } \\
\text { overall experience. }\end{array}$ & $\begin{array}{c}\text { (2) Please rate the } \\
\text { content of the } \\
\text { clinic. }\end{array}$ & $\begin{array}{c}\text { (3) Please rate } \\
\text { the instructors. }\end{array}$ \\
\hline $\begin{array}{c}\text { Average ratings for sessions } \\
\text { without prizes }(N=245)\end{array}$ & 5.59 & 5.76 & 5.98 \\
\hline $\begin{array}{c}\text { Average ratings for sessions } \\
\text { with prizes }(N=43)\end{array}$ & 5.53 & 5.79 & 6.05 \\
\hline $\begin{array}{c}\% \text { Increase of sessions with } \\
\text { prizes over those without }\end{array}$ & $-1.1 \%$ & $0.5 \%$ & \\
\hline $\begin{array}{c}\% \text { Increase of sessions with } \\
\text { case studies over those with } \\
\text { prizes }\end{array}$ & $2.9 \%$ & $2.3 \%$ & $0.6 \%$ \\
\hline
\end{tabular}

TABLE 3. Attendee satisfaction ratings for clinics depending on how they respond to the Question, "How did you learn about this clinic?" (Attendees can mark more than one.)

Average ratings from respondents citing

(1) Please rate your overall experience.
(2) Please rate the content of the clinic.
(3) Please rate the instructors.

\begin{tabular}{|cccc|}
\hline Posters $(N=100)$ & 5.77 & 5.86 & 6.03 \\
\hline Fliers $(N=23)$ & 5.52 & 5.78 & 6.09 \\
\hline Professors $(N=146)$ & 5.49 & 5.75 & 5.92 \\
\hline Other Students $(N=26)$ & 5.58 & 5.58 & 5.81 \\
\hline Email $(N=44)$ & 5.77 & 5.84 & 6.25 \\
\hline Website $(N=5)$ & 5.60 & 5.20 & 6.00 \\
\hline
\end{tabular}

